\title{
MÁS SOBRE LOS ORÍGENES DE CIVILIZAR Y CIVILIZACIÓN EN LA ESPAÑA DEL SIGLO XVIII
}

\begin{abstract}
Justement parce que civilisation est un de ces mots qui inculquent une vision nouvelle du monde, il importe de préciser autant qu'on le peut les conditions dans lesquelles il a été créé.
\end{abstract}

Émile Benveniste.

Benveniste ha indicado el interés que, para describir el vocabulario de la cultura moderna, tendrían los trabajos dedicados a estudiar con detalle, en cada una de las diferentes lenguas, las palabras que componen este vocabulario común ${ }^{1}$. Sin duda, es civilización una de sus voces esenciales. Por ello quisiera insistir una vez más en los orígenes de este neologismo en España, ampliando aquí la obligada brevedad de un trabajo anterior ${ }^{2}$.

\section{Civilización y ReForma De COSTUMbres}

En el Dictionnaire de Trévoux, en la edición de 1771, se define así la palabra francesa civilisation:

terme de jurisprudence. - - 'est un acte de justice, un jugement qui rend civil un procès criminel. La civilisation se fait en convertissant les informations en enquête, ou autrement. - L'ami des hommes a employé ce mot pour sociabilité. Voyez ce mot. La religion est sans contredit le premier et le plus utile frein de l'humanité; c'est le premier ressort de la civilisation. Elle nous prêche, et nous rapelle sans cesse la confraternité, adoucit notre cceur ${ }^{3}$.

1 "Civilisation: contribution à l'histoire du mot", en Problèmes de linguistique générale, Gallimard, Paris, 1966, p. 336. Trad. española de Juan Almela, Siglo XXI, Mćxico, 1971.

2 "Civilizar, civilizado y civilización: una polémica de 1763", $C H(7), 419-427$.

3 Apud JOACHIM MoRas, Ursprung und Entwicklung des Begriffs der Zivilisation in Frankreich (1756-1830), Seminar für romanische Sprachen und Kultur, Hamburg, 1930, p. 5. 
La acepción jurídica ya se hallaba consignada en las ediciones anteriores del mismo diccionario. La novedad consiste en la segunda acepción referida a sociabilité y el texto al que remite, un pasaje de la obra del marqués de Mirabeau, L'ami des hommes ou Traité de la population, publicada anónimamente en Aviñón el año 1756. Como señaló Joachim Moras $^{4}$, en 1930, es en este pasaje donde la palabra aparece por primera vez con un nuevo sentido cultural y social derivado del verbo civiliser, definido en el mismo diccionario como verbo activo:

Rendre civil et poli, traitable, sociable. Aliquem ad omne officii munus instruere. La prédication de l'Evangile a civilisé les peuples barbares les plus sauvages. Ad humanitatem informare. Il n'y a rien de plus propre à civiliser et à polir un jeune homme que la conversation des Dames.

Desde mediados del siglo XVI el verbo está atestiguado en francés en un texto de Amyot, de 1550: "Janus leur institua le bon gouvernement, en leur establissant de bonnes loix, et civilisant leur manière de vivre""5. Según Amyot, el buen gobierno depende de las buenas leyes, de la police, y de las buenas costumbres, de la politesse, dos conceptos que entran como ingredientes semánticos en la substantivación dieciochesca del verbo civiliser. Después aparece en Montaigne con el sentido de adquirir cortesía y en Descartes ${ }^{6}$, que considera que un pueblo debe de estar civilisé como condición previa para estar policé. Los diccionarios franceses del siglo XVII (Richelet, Académie, Furetière) hacen sinónimos civiliser y polir, poniendo ejemplos iguales o semejantes a los que hemos visto en el diccionario de Trévoux. En el diccionario de la Académie, civiliser equivale a "polir les mœurs": "le commerce des Grecs a civilisé les Barbares"7. Como se puede ver en los ejemplos de estos diccionarios, la sinonimia civiliseripolir se presta a interpretaciones amplias cuando estos verbos se emplean para expresar la acción de refinar las costumbres ("polir les mœurs"), alejando a los pueblos de la barbarie y la ignorancia. Los pueblos "policés" son pueblos "polis" y "civilisés".

J. Moras señala cómo en los primeros usos del neologismo civilisation el verbo civiliser se mantiene vigorosamente en el sustantivo; es la acción de civilizar, consistente en "adoucir". En el pasaje citado por el diccionario de Trévoux, “ 'adoucir' ist nur eine Umschreibung für 'civiliser' "'8. Hacia 1768, Mirabeau atestigua que para la mayoría de

También en Benveniste, op. cit., p. 338 . Véase la nota 2 de dicha página para las correcciones de Benveniste al Dictionnaire étymologique de Bloch-Wartburch.

4 Moras, op. cit., p. 35.

5 Apud Georg Michael Pflaum, Geschichte des Wortes "Zivilisation", InauguralDissertation zur Erlangung des Doktor Grades der Philosophischen Fakultät der LudwigMaximilianus-Universität zur München, 1961, p. 5.

6 Véase LuCien Febvre, "Civilisation. Évolution d'un mot et d'un groupe d'idées", en Civilisation. Le mot et l'idée, La Renaissance du Livre, Paris, 1930, p. 9.

7 Segunda edición, 1695. Slatkine Reprints, Genève, 1968.

8 Moras, op. cit., p. 7. 
sus lectores civilisation significa "adoucissement des mœurs"'. Comparando diferentes pasajes en que este autor utiliza la nueva palabra, resulta, según Benveniste, que para Mirabeau, civilisation es 'l'effort pour amener l'individu à observer spontanément les règles de la bienséance et pour transformer dans le sens d'une plus grande urbanité les mœurs de la societé" 10 . J. Moras indica que el autor de L'ami des hommes, profundizando moralmente esta concepción del refinamiento de las costumbres, implícita en civilisation, se opone a la superficialidad y a la mera exteriorización de los ideales implicados en las palabras civiliser / adoucir, polir / policer; es decir, se vuelve contra lo que podría parecer apenas algo más que la superficialidad de una cultura social, contra lo que el mismo Mirabeau considera "fausse civilisation"11.

La reforma de las costumbres, por encima de la superficialidad de la moda y como aspecto integrante de la civilización, es un proceso necesario en la aspiración a alcanzar el modelo ideal de individuo y de sociedad tal como lo concibe la Ilustración. Se puede ver esto en la definición del neologismo en un diccionario alemán de la lengua francesa, citado por Moras, Nouveau dictionnaire fraņ̧ais, contenant les expressions de nouvelle création du peuple français, publicado en 1795 por Leonard Snetlage, en que civilisation se explica como "Sittenverfeinerung oder vielmehr Sittenverbesserung" (refinamiento de costumbres o más bien mejoramiento de costumbres):

employé pour exprimer l'action de civiliser ou la tendance d'un peuple de polir ou plutôt de corriger ses mœurs et ses usages en portant dans la société civile une moralité lumineuse, active, aimante et abondante en bonnes œuvres. (Chaque citoyen de l'Europe est aujourd'hui parti dans ce dernier combat de civilisation. Civilisation des mœurs) ${ }^{12}$.

La acción de refinar y mejorar las costumbres de un pueblo se entiende aquí como progreso de la moral social, expresión ideológica de una nueva moralidad ilustrada y revolucionaria. Es una acción moral dirigida al perfeccionamiento de la sociedad civil a lo largo del desarrollo histórico de la humanidad. Como indica F. Braudel, el sustantivo civilisation designa desde su nacimiento "un idéal profane de progrès intellectuel, technique, moral, social. La civilisation, c'est les 'lumières' '. Y añade que "elle ne peut guère s'imaginer sans qu'il y ait, pour la soutenir, une societé de bon ton, fine, 'policée' "',13. Es decir que el concepto diecio-

9 En el borrador del comienzo de una obra que no llegó a terminar, $L$ 'ami des femmes ou Traité de la civilisation. Véase Moras, op. cit., pp. 37-39, y Benveniste, op. cit., pp. 338-339.

10 Benveniste, op. cit., p. 339.

11 Moras, op. cit., pp. 37-38.

12 Apud Moras, ibid., pp. 8-9.

13 F. BRAUdEL, "L'histoire des civilisations: le passé explique le présent', en Écrits sur l'histoire, Paris, 1969, pp. 259-260. 
chesco de civilisation se construye sobre la base semántica establecida por las virtudes civiles propias de la nueva sociedad burguesa.

\section{LOS PRIMEROS TESTIMONIOS EN ESPAÑA: GIVILIZACIÓN CONTRA GIVILIZAR}

La introducción en los diferentes países europeos del vocabulario común a que se refiere Benveniste nos puede dar indicios de cómo adquiere vigencia el pensamiento moderno en cada uno de ellos ${ }^{14}$. Pero la aparición de una palabra nueva de este vocabulario común nos dirá poco a este respecto si no tenemos en cuenta las circunstancias precisas en que surge el neologismo. En comparación con otras lenguas, civilización aparece muy temprano en el español escrito, si bien no puede decirse de la sociedad española del siglo Xvir lo que F. Braudel dice de la francesa de la misma época, que "en este término de civilización, la sociedad francesa del final del reinado de Luis XV reconoce, con complacencia, su propia imagen"' "Para los españoles civilización es un espejo que refleja una imagen ajena: para unos, un modelo ideal que hay que imitar, para otros, un ejemplo perverso y seductor del que hay que huir como del diablo. En todo caso, ni para unos, ni para otros podía significar una actitud de complacencia, sino una actitud conflictiva con respecto al propio país.

Como traté de mostrar en el trabajo antes mencionado, la palabra civilización surge, quizá por primera vez en español escrito, en una polémica relacionada con el problema de la modernidad en la España del siglo Xvin. Durante 1763, siete años, por lo tanto, después de que el marqués de Mirabeau la empleara por primera vez en francés, la vemos escrita tres veces en español, una en El escritor sin título, revista satírica de Cristóbal Romea y Tapia ${ }^{16}$, y dos en el sainete La civilización, de Ramón de la Cruz ${ }^{17}$. El primero la utiliza en medio de una polémica con Francisco Mariano Nifo sobre la cuestión de si España era un país civilizado o estaba aún por civilizar, polémica a la que alude sarcástica-

14 Véase RAFAel LAPESA, "Ideas y palabras: del vocabulario de la Ilustración al de los primeros liberales", Asclepio, 18/19 (1966-1967), 189-218; MARIAN SerejSKI, "Les origines et le sort des mots civilisation et culture en Pologne", AESC, 17 (1962), 1107-1116; Raymond Williams, Keywords. A vocabulary of culture and society, Fontanal Croom Helm, London, 1976.

${ }^{15}$ Las civilizaciones actuales, trad. de J. Gómez Mendoza y G. Anes Álvarez, Tecnos, Madrid, 1966, p. 13.

16 El escritor sin título, Manuel Martín, Madrid, 1763. Para la reseña bibliográfica de los periódicos a que aquí nos referimos, véase Francisco Aguilar Piñal, La prensa española en el siglo xuiii, C.S.I.C., Madrid, 1978. También Paul-J. Guinard, La presse espagnole de 1737 à 1791, Institut d'Études Hispaniques, Paris, 1973.

${ }^{17}$ En Sainetes de Ramón de la Cruz, ed. de E. Cotarelo y Mori, Bailly/Bailliére, Madrid, 1915, t. 1, pp. 95-101. El sainete fue estrenado el 18 de octubre de 1763. Véase E. Cotarelo y MORI, Don Ramón de la Cruz y sus obras. Ensayo biográfico y bibliográfico, Perales y Martínez, Madrid, 1899, p. 44, nota 1. 
mente Ramón de la Cruz en su sainete, poniéndose del lado del periodista satírico.

Tanto el autor de la revista satírica como el del sainete se manifiestan "españoles castizos", como ya se decía entonces ${ }^{18}$, contra los intentos modernizadores y extranjerizantes de la política oficial reformista propagados entonces por Nifo en sus periódicos Estafeta de Londres, de 1762 , Diario extranjero y Correo General de Europa, de $1763^{19}$, y por José Clavijo y Fajardo en El Pensador, publicación iniciada en 1762 y que duró, con interrupciones, hasta $1767^{20}$. Los tres primeros discursos de El escritor sin título van dirigidos al autor de las "Noticias de Moda", es decir, a Francisco Mariano Nifo que en su Diario extranjero incluía una sección con dicho título dedicada a reseñar las representaciones teatrales de los escenarios madrileños. Romea y Tapia lo acusa de extranjerizante y declara:

El objeto de este papel [no] se reduce a otra cosa que a poner algunas reflexiones a las Noticias de Moda; sólo porque estoy muy mal con que se nos quiera aplastar con el ejemplo de las Naciones Extranjeras para prescribir nuestra diversión (I, pp. 9-10) ${ }^{21}$.

Los dos discursos siguientes - el cuarto y el quinto- constituyen una apología de los autos sacramentales de Calderón, contra las críticas expresadas, siguiendo la política oficial, en los números - "pensamientos" - 42, 43 y 44 de la revista de Clavijo y Fajardo. Según El Pensador, en otros países, como Francia e Italia, también se dieron representaciones semejantes a los autos sacramentales: "Pero esto sólo sucedió en

18 Por ejemplo, LuIS JAYme, en La comedia española defendida, Imprenta del Diario, Madrid, 1762, p. 5, dice: "He visto una disertación contra nuestras comedias y una comedia nueva, para ejemplo de cómo se han de formar según arte. Uno y otro me enfadó y diome la gana de escribir esta carta. Y nada se me dará de que no agrade a los Críticos, porque no tengo genio, ni tiempo para la disputa. A estos les cedo, desde ahora, el campo: hablo sólo con los Españoles castizos, amantes de nuestros sabios poetas cómicos" (el subrayado es mío).

19 Estafeta de Londres. Obra periódica, repartida en diferentes cartas en las que se declara el proceder de la Inglaterra respecto a sus costumbres, Industria, Artes, Literatura, Comercio y Marina, por Don Mariano de la Giga, Gabriel Ramírez, Madrid, 1762. Correo General, histórico, literario y económico de la Europa (en continuación de la Estafeta de Londres), donde se contienen memorias útiles sobre las ciencias, agricultura, artes y comercio de Francia, Holanda, Alemania, Italia y demás Reinos y Provincias europeas que saben sacar su felicidad de una prudente y bien dirigida economía pública. . . Por Don Francisco Mariano Nipho y Cagigal, Gabriel Ramírez, Madrid, 1763. Diario Estrangero. Noticias importantes y gustosas para los verdaderos apasionados de Artes y Ciencias que ofrecen en el día los Reinos civilizados de Europa. . . Por Don Francisco Mariano Nipho, Gabriel Ramírez, Madrid, 1763.

20 El Pensador. Por Don Joseph Álvarez Valladares, J. Ibarra, Madrid, 1762. A partir del segundo tomo se sustituye el seudónimo por el nombre verdadero del autor.

21 Para el aspecto literario de esta polémica, véase I. L. MCClelland, The origins of the Romantic movement in Spain, Institute of Hispanic Studies, Liverpool, 1937, pp. 89-90. 
los siglos bárbaros"' (III, 42, p. 412), mientras que en España "los Autos prosiguen en todo su vigor, ayudando a confirmar el concepto de bárbaros, que hemos adquirido entre las Naciones"' (IV, 43, p. 12). Las mismas razones que movieron a Romea y Tapia contra Nifo lo llevan ahora a atacar a Clavijo y Fajardo. Del mismo modo que se indignaba de que Nifo considerara a España un país sin civilizar, al Pensador le reprocha que él mismo subscriba el concepto de bárbaros atribuido a los españoles por los extranjeros ${ }^{22}$.

En cuanto al sainete de Ramón de la Cruz, E. Cotarelo y Mori advirtió que La civilización tenía "visos de sátira personal", que él atribuía " a las cuestiones relativas a nuestro atraso, planteadas por El Pensador principalmente". Cotarelo se basaba para estas suposiciones en la nota de un contemporáneo, contenida en la Censura del doctor D. Celestino Antero a la obra de D. Jacinto María Delgado, Adiciones al Quijote (1780). La nota decía así: "Por la voz, que imprimió de buena fe cierto quidam, que dijo que estábamos sin civilizar, yo mismo le vi convertido en héroe de un sainete que se representó alguna vez en el coliseo de los polacos. . . "23 Aunque indudablemente la sátira de La civilización alcanzara indirectamente al periódico de Clavijo, el quidam objeto personal de los ataques, secundando a Romea y Tapia, era Nifo. Como veremos luego, a él era a quien El escritor sin título (I, p. 20) había atribuido la opinión de que "España está todavía por civilizar", satirizada por el sainete.

De estos periódicos de Nifo y de Clavijo y Fajardo se podría decir lo que P.-J. Guinard señala del primero de ellos, la Estafeta de Londres, que parecen publicaciones "de propagande rédigée(s) à la demande ou sur la suggestion du Secrétariat d'Etat', aunque, por falta de pruebas documentales, no se atreva a asegurarlo ${ }^{24}$. En todo caso, respondían a los puntos de vista del Gobierno. Esto explicaría, en parte, las contradicciones ideológicas de Nifo, señaladas por Luis Miguel Enciso Recio, por un lado "radicalmente anclado en la tradición", intolerante de "mentalidad inquisitorial", y por otro, partícipe de "la devoción naturalista, racional y utilitaria, propia del pensamiento moderno"'25. Si sus

22 Después de citar el pasaje del Pensador, transcrito por nosotros en el texto, en que Clavijo y Fajardo considera que la representación de los autos sacramentales contribuye a confirmar el concepto de bárbaros que los españoles han adquirido entre las Naciones, Romea y Tapia comenta: "Pues sobre ser Vm. del mismo concepto que las Naciones, no creo que éstas muden de dictamen, si efectivamente lo tienen por los pensamientos, que tal vez tuvieron entre ellas su cuna' (V, p. 142).

23 Don Ramón de la Cruz y sus obras, cd. cit., p. 43.

24 P.-J. Guinard, op. cit., p. 131. Guinard también recoge el testimonio de un viajero inglés, R. Twiss, sobre los rumores de que Ricardo Wall, Secretario de Estado entre 1754 y 1763 , había colaborado en El Pensador, cf, ibid., p. 177. Sobre la protección oficial a este periódico, véase.J. SEMPERE y GUARINOS, Ensayo de una biblioteca, t. 4, pp. 177-178.

25 Luis Miguel Enciso Recio, Nipho y el periodismo español, Universidad, Valladolid, 1956, pp. 56 y 58. Del Correo General de Europa dice Enciso Recio: “El pensa- 
ataques al teatro español provocan en Romea y Tapia la acusación de extranjerizante, su folleto La nación española defendid ${ }^{26}$ lo concilia con $\mathrm{El}$ escritor sin título ${ }^{27}$.

En sus publicaciones de 1762 y 1763 , Nifo utiliza reiteradamente el verbo civilizar para expresar la necesidad de una regeneración económica, cultural y moral que levante el país al grado de progreso alcanzado por los países civilizados en el cultivo de las ciencias, la industria, la agricultura, el comercio, las artes, y en el perfeccionamiento de las costumbres sociales. En España, según el Correo General de Europa, "las costumbres más regulares y conformes a la moral y a las leyes producirían todas aquellas progresivas felicidades que hoy disfrutan los reinos civilizados de Europa"' (I, p. 7). Y en cuanto al teatro, se dice en el Diario extranjero: "Mientras duren estas representaciones, ni se civilizará nuestra Nación, ni se perfeccionarán nuestras costumbres"' (VI, p. 87).

Tanto como el orden en las costumbres importa el progreso en las ciencias y en las artes. En el Correo General de España (I, p. 67), leemos:

España es un pedazo del mundo. . . donde nacen hombres que a no conducirlos el cuidado de la educación, se equivocaría con los salvajes, lo mismo que sucedería con los reinos que blasonan de civilizados y cultos en la Europa. Francia, Italia, Alemania, Inglaterra y cuantos reinos tienen por sus moradores las ciencias y las artes, serían lo mismo y algo menos que la España si entre ellos, como entre nosotros, dominara la desunión y la negligencia.

Para el redactor de este periódico, civilizar es una empresa política del Estado:

Tócale a la prudencia política de cada Estado imitar tan sabio y conveniente ejemplo [ias universidades de Inglaterra], y fundar en sus universidades esta especie de beneficios reales para el progreso de las Ciencias, para el adelantamiento de la juventud, y para conseguir facilísimamente la gloriosa, y alta empresa de pulir, y civilizar la Nación (I, p. 89, el subrayado es mío).

miento ilustrado está presente en esta obra más quizá que en ninguna otra de las periódicas atribuibles a Nipho"' (ibid., p. 251). Pero cuando en este periódico inserta, como luego veremos, algunos pasajes traducidos de las Instituciones políticas, del barón de Bielfeld, excluye uno en que se ataca a la intolerancia, porque "se opone directamente a la pureza y sanos sentimientos de esta Península" (I, p. 323).

${ }^{26}$ La Nación española. Defendida de los insultos del Pensador, y sus secuaces, Gabriel Ramírez, Madrid, 1764.

27 En el último discurso de la revista, Romea y Tapia dice refiriéndose al autor de las "Noticias de Moda": "Hoy no puedo dejar de congratularme y dar muchas gracias a Dios, pues el señor que lo decía [que estábamos incivilizados] ex inimico factus est amicus"' (XI, p. 331). 
El verbo civilizar era una palabra que se hacía necesaria en español para expresar la aspiración regeneradora que venía manifestándose desde finales del siglo XVII en los escritos de los novatores, como podemos ver en el texto de Juan de Cabriada, de 1687, transcrito por J.M. López Piñero en su libro La introducción de la ciencia moderna en España:

Que es lástima y aun vergonzosa cosa que, como si fuéramos indios, hayamos de ser los últimos en recibir las noticias y luces públicas que ya están esparcidas por Europa. Y asimismo, que hombres a quienes tocaba saber esto se ofendan con la advertencia y se enconen con el desengaño. ¡Oh, y qué cierto es que el intentar apartar el dictamen de una opinión anticuada es de lo más difícil que se pretende en los hombres! $!^{28}$

¡España se equivocaría con los salvajes, como si fuéramos indios con respecto a los demás países de Europa! Esta advertencia y este desengaño es lo que ofende y encona a Cristóbal Romea y Tapia, "español - según él- a prueba de bomba" (I, p. 3), cuando en El escritor sin título reacciona contra los intentos de "civilizar nuestra Nación", preconizados por las "Noticias de Moda":

lo que no se puede llevar en paciencia es que en nuestras barbas e impunemente se estampe: Mientras duren estas perjudiciales representaciones [teatrales], no se civilizará nuestra Nación, ni se perfeccionarán nuestras costumbres. ¿Qué es esto? ¿España está todavía por civilizar? ¿Qué más queda por decir de lo más oculto de California y de los países adonde no ha llegado la Política, Religión ni Gobierno. . . No hay paciencia para leer expresiones menos penetrantes en los extranjeros y la hemos de tener para escucharlas en nuestros paisanos? (I, pp. 20-21).

Es en medio de esta polémica sobre si España era un país civilizado o estaba todavía por civilizar donde, por primera vez que sepamos, aparece en español la palabra civilización, en la pluma de Romea y Tapia, que la escribe para indicar un concepto, según él, dañino y venenoso: "porque a la verdad, si yo digo de los españoles, que es gente por civilizar (es un áspid, una furia, un veneno esta civilización) ¿qué me tocará a mí que no soy chorizo, digo polaco, ni holandés?"' (II, p. 35). Como él no es más que "un pobrete Castellano viejo, o Aragonés mozo, que todo se va allá" (VII, p. 202) , $^{29}$ se siente ofendido por el verbo que

${ }^{28}$ La introducción de la ciencia moderna en España, Ariel, Barcelona, 1969, pp. 5 y 105-106. Dice Pierre Vilar: " 'Nos tratan como indios' ha sido la fórmula utilizada por los españoles desde el siglo XVI para expresar su frustración ante los europeos, que, a fin de cuentas, aprovecharon mejor que ellos los tesoros de América. A fines del siglo XVIII, el reproche había pasado a ser intelectual y la referencia al indio de Asia, colonizado por los franceses y por los ingleses" ("Patria y nación en el vocabulario de la guerra de la Independencia española", en Hidalgos, amotinados y guerrilleros, trad. de Ferrán Gallego, Crítica, Barcelona, 1982, p. 231). El "como si fuéramos indios" ya expresa en Juan de Cabriada una frustración intelectual.

${ }^{29}$ Romea y Tapia era, efectivamente, aragonés. Había nacido en Daroca, en 
considera ofensivo y hasta herético en cuanto que pone en peligro el carácter tradicional de España:

Pues - dice a continuación - no hay más que darle, enherbarse (sic) bien y no publicar escrito que no se le pegue cuatro tarascadas a la madre que nos cría, nos alimenta, nos viste, nos calza, nos enseña una fe pura, sin mezcla de opiniones y sectas descarriadas, el verdadero culto, la constancia, la fidelidad, que nos singulariza entre todas las Naciones: la sobriedad, que si ha padecido algún disturbio, ha sido por la comunicación de los modelos que nos presentan y quieren embutir a fuerza de brazos; pero luego con una conterita, de que nos mueve el amor, el bien común, o alguna otra cosuela, podremos dorar los yerros de nuestra ingratitud ${ }^{30}$.

La primera vez, por lo tanto, que vemos escrita en español la palabra civilización aparece para ser rechazada, como reacción en contra de los que quieren modernizar la nación siguiendo el ejemplo de los países extranjeros. Fijémonos que este primer testimonio viene precedido de un demostrativo ("esta civilización") cuya función deíctica es de carácter textual, alude anafóricamente a un concepto expresado con anterioridad en el texto, el concepto asociado al verbo civilizar, del cual Romea y Tapia construye espontáneamente una derivación sarcástica que, poco después, Ramón de la Cruz reproduce con la misma intención satírica. También con sentido peyorativo construye Romea y Tapia, con menos fortuna, otra sustantivación, civilizamiento ("civilizamiento de mis pecados"), para expresar igualmente la acción del verbo civilizar y en contra de su significación extranjerizante ${ }^{31}$.

1732. Murió en 1766. También Nifo era de Aragón. Nacido en Alcañiz en 1719, murió en 1803 .

30 Subrayado en el original. A este pasaje se refiere en el siglo siguiente N. Bóhl de Faber. Según C. Pitollet, en un artículo del Diario mercantil, de Cádiz, Bóhl comenta algunos pasajes del Escritor sin título diciendo que "es imposible leer estas sencillas reflexiones sin penetrarse de la verdad de que los más encarnizados enemigos de la cultura española han salido de su propio seno, y que sólo la España ha tenido hijos tan descastados que hagan comercio en manifestar las faltas de su madre, y luego con una conterita de que los mueve el 'amor', el 'bien común', o alguna otra cosuela, piensan dorar los hierros de su ingratitud'. (La querelle caldéronienne, Alean, Paris, 1909, pp. 133-134). GuIllermo CARnERO, Los orígenes del romanticismo reaccionario español, Universidad, Valencia, 1978, p. 196, también reproduce este texto de Bóhl/Romea y Tapia, sin el subrayado que aparece en la transcripción de Pitollet. Yo no he visto el original. Pitollet confunde, como Cotarelo y Mori (véase nota 23), a Nifo con Clavijo y Fajardo, a quien atribuye las "Noticias de Moda" del primero.

31 En el discurso II, pp. 44-45: “¿Qué puede conducir para las ciencias la Comedia, ni qué civilizamiento de mis pecados es ése, cuando en algunos tratados extranjeros, cuyo objeto es satirizarnos, no han podido enemistarse con una verdad tan notoria, como que España ha sido pocos siglos antes de ahora la verdadera morada de las ciencias, y que los ingenios españoles han sido siempre los más sobresalientes? Dime, pues, por tu vida, ¿pocos siglos antes de ahora teníamos mejores comedias? ¿Estábamos civilizados? Sin duda; porque España era la verdadera morada de las ciencias"'. (Subrayado en el original.) 
En su sainete, Ramón de la Cruz se sirve del tópico de contraponer las virtudes del campo a los vicios de la ciudad de donde viene la civilización. La aldea representa las costumbres antiguas, toscas, pero virtuosas:

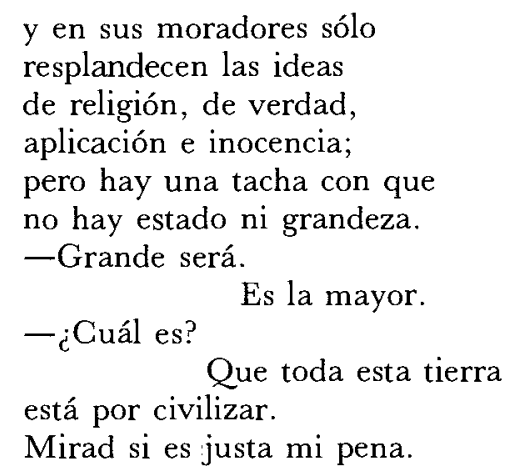

El que así se lamenta es un marqués que acaba de heredar una aldea y se avergüenza de la tosquedad y del atraso de sus vasallos. Para remediar tan triste situación, hace venir de la corte algunos civilizantes o civilizadores para civilicear o civilizar a los campesinos con las modernas costumbres de la ciudad. Son un abogado, un abate "muy pulido", un petimetre y dos petimetras que

son pasantas o maestras

de la civilización.

El marqués les expone su proyecto y los reformadores se aprestan a llevarlo a cabo:

Denos usía el timón

del estado, y a la vuelta

de una semana estarán

todas las cosas perfectas.

Una de las propiedades

desta política nueva

es reírse de las cosas

que usaron nuestras abuelas.

$\mathrm{Y}$ aunque sean excelentes,

en viendo que algo semejan

a la antigüedad los usos,

hacer burla manifiesta.

Los aldeanos se rebelan cuando los civilizadores pretenden civilizar la Iglesia y amenazan con denunciarlos a la Inquisición: 
Si otra proposición suelta por el término, a la Santa i.juro a Dios! que he de dar cuenta. Sufriremos que nos echen la albarda y la gurupera; pero no consentiremos que a civilizar la Iglesia se atreva nadie.

Los aldeanos amenazan "civilizarles la testa" a los "civilizantes" y el marqués se arrepiente de sus proyectos políticos. La civilización parece una alegoría política ${ }^{32}$.

De todos modos, en 1763 , civilización y civilizamiento eran palabras raras y precisamente de su carácter insólito recibían gran parte de su fuerza satírica, como civilicear, civilizantes y civilizadores, utilizadas en el sainete. Además del título, civilización sólo aparece una vez en el sainete, en el lugar que antes hemos citado. Junto a civilización emplea el antiguo término civilidad ("La civilidad me trae / todas las tripas revueltas" $\mathrm{y}$ "s. . que son estas leyes nuevas / de civilidad. ¡Oh, nombre, / qué dulce pones la lengua!'”), que era el sustantivo a que los partidarios de civilizar recurren insatisfactoriamente, ya que la palabra ("Sociabilidad, urbanidad, policía", según el Diccionario de Autoridades) se quedaba corta oara significar la idea de progreso y de desarrollo histórico que expresaban con el verbo. Civilidad, como el francés civilité, era un término estático ${ }^{33}$, desprovisto del sentido de progresión. Por otra parte, su limitada asociación con "sociabilidad" y "urbanidad" restringía su ámbito significativo, excluyendo otros aspectos distintos de las costumbres, como las ciencias, la economía y las artes, implicados en el progreso significado por el verbo civilizar. Para la contraposición con "barbarie" vemos urilizado este infinitivo, y no civilización, ni civilidad, cuando Juan Antonio Aragonés, en su periódico El amigo del público, escribe, aludiendo también a la polémica, que "ya parece que no se oyen tanto aquellas voces malsonantes de civilizar y barbarie con que nos han machacado y molido hasta los huesos" 34 . Sin embargo, como se puede comprobar en los ejemplos aducidos por José Antonio Maravall ${ }^{35}$, y en otros an-

32 "Como se ve — dice Pedro Álvarez de Miranda-, la postura del sainetero no puede ser más reaccionaria: con el tradicionalismo nostálgico que le es habitual, Cruz banaliza al máximo la idea de civilización identificándola con la importación de modas corruptoras. Es una eficaz manera de halagar los oídos del pueblo, indisponiéndole con la clase ilustrada dirigente"'. Introducción a la edición del Tratado sobre la Monarquía Columbina, El Archipiélago, Madrid, 1980, p. L.

33 Véase E. Benveniste, op. cit., p. 340.

${ }^{34}$ El amigo del público, que sin doblez le habla, y continúa en desengañándole, haciendo una breve crítica de varios papeles sueltos. Escrito en prosa y verso por su autor el Dr. D. Juan Antonio Aragonés, Abogado de los Reales Consejos, Antonio Muñoz del Valle, Madrid, 1763, discurso III, p. 19.

35 José Antonio Maravall, "La palabra 'civilización' y su sentido en el siglo XVuI', $C H(5), 79-104$ 
teriores, como veremos luego, el sustantivo civilización, contrariamente a lo que creía Werner Krauss ${ }^{36}$, pronto va a ser aceptado por los ilustrados españoles, reemplazando a civilidad, para expresar la acción de civilizar y el estado a que llegan los pueblos civilizados.

Al no tener en cuenta el contexto polémico en que Ramón de la Cruz escribió su sainete La civilización, contexto desconocido también por Maravall, y apoyado en otros textos donde civilizar se emplea con la misma intención satírica, generalizó sus escasos datos, afirmando que el término escrito en Francia desde 1756, "'a los siete años pasará los Pirineos, pero sin obtener en España una recepción amistosa'. Y añade que "se recibió la palabra para repudiarla" 37 . Pero, como hemos visto, la palabra utilizada por Ramón de la Cruz para el título del sainete, en el cual se basa Krauss para su argumentación, no parece que sea una importación, sino una derivación espontánea y directa de Romea y Tapia a partir del verbo civilizar, cuando civilisation en Francia se usa raramente. En efecto, desde 1756 hasta 1763, año en que emplean la palabra los dos autores españoles, sólo se han podido atestiguar en francés seis casos en los escritos de Mirabeau. Los testimonios en otros autores franceses son posteriores a los españoles (Boulanger en 1766) ${ }^{38} \mathrm{y}$ el primer ejemplo inglés de civilization no se ha podido fechar por el momento antes de 1767 en un texto de Adam Ferguson aportado por Benveniste, según el cual no parece que este autor escocés pudiera inspirarse en Mirabeau, ni siquiera que lo conociera ${ }^{39}$. Lo mismo podría decirse de Romea y Tapia. Quien sí conocía la obra en que aparece por primera vez la palabra en francés era Nifo ("nadie - dice en el Correo General de Europa, (II, p. 193) - como el Marqués de Mirabeau en su Tratado del Amigo de los Hombres ha manifestado tan finamente el carácter de un buen Ciudadano''); sin embargo, nunca, oue sepamos, utiliza el neologismo civilización, sino el término civilidad ${ }^{40}$.

En estos primeros testimonios españoles del neologismo, civilización surge para oponerse al verbo civilizar. Ésta es la palabra que realmente se importa de Francia, y para atajar su novedoso prestigio en los periódicos donde se propaga la política reformista oficial, crea Romea y Tapia las sustantivaciones satíricas de civilización y civilizamiento. Precisamente, a la recepción amistosa obtenida por el verbo civilizar es a lo que trata de enfrentarse el Escritor sin título cuando escribe que si la Naturaleza " nos ha puesto una pantalla mocha y calva que forman los Pirineos ha sido sin duda para distinguirnos hasta el aire que respiramos"' (III, p. 77). Para los españoles castizos, los intentos de "civilizar la nación" no sólo

36 Werner Krauss, "Sobre el destino español de la palabra francesa 'civilisation' en el siglo XVII"', BHi, 69 (1967), 436-440.

37 Ibid., p. 436.

38 Véase J. Moras, op. cit., pp. 35-49. Sobre el texto de Boulanger, véase L. Febvre, op. cit., pp. 5-6.

39 Véase Benveniste, op. cit., p. 344.

40 Véase infra. 
resultaban ofensivos, sino, aún más, peligrosos, sobre todo si estaban respaldados por la política oficial del despotismo ilustrado. Éste es el motivo por el cual la primera vez que encontramos la palabra civilización, escrita para expresar la acción de civilizar, oponiéndose a ella, aparece como una palabra venenosa en la pluma de un periodista reaccionario.

\section{EL VERBO CIVILIZAR EN ESPAÑOL}

Lo que importa para estudiar los orígenes del concepto de civilización en España es que nos fijemos en cómo empieza a utilizarse el verbo civilizar en el español del siglo XviII para expresar una acción política, impulsada por la moderna ideología de la Ilustración e inspirada por su prestigio. Al ser adoptado el verbo a mediados del siglo, viene ya precedido de una tradición semántica en otras lenguas europeas, especialmente en francés, que determina su significado en la nueva lengua de adopción. Civilizar pasa los Pirineos para sintetizar verbalmente todo un ideal de modernidad y una aspiración de progreso, con respecto a una realidad nacional que se considera atrasada y decadente.

A finales del siglo XVII hemos visto la noción expresada por Juan de Cabriada cuando dice "como si fuéramos indios": a mediados del siglo siguiente se podría haber dicho "como si estuviéramos por civilizar". En Feijoo esperaríamos encontrar la expresión "pueblos civilizados', pero el verbo no forma parte de su vocabulario. Pedro Álvarez de Miranda ha indicado que en este autor la "barbarie" equivale a "falta de cultura", "lo cual nos da una idea de la cercanía entre la idea de cultura y la que muy pronto va a expresarse con la palabra civilización" 41 . De hecho, cuando poco después veamos la expresión "pueblos civilizados" normalmente empleada en español, la veremos, a veces, reforzada con el adjetivo culto ("pueblos cultos y civilizados") o identificada simplemente con "pueblos cultos". Pero ya en la época del Teatro crítico universal aparece en español el verbo civilizar con el significado de adquirir cultura, expresando el proceso de mejoramiento por el cual un pueblo llega a superar el estado primitivo de esa falta de cultura. En este sentido lo emplea Gregorio Mayans cuando en el libro Orígenes de la lengua española, publicado en 1737, escribe:

los Cántabros, digo, que en aquel tiempo era una gente inculta e intratable, se civilizaron después de tal manera que se aplicaban a las Letras, y especialmente a la Filosofía Estoica ${ }^{42}$.

Entre 1762 y 1763 el verbo asume una significación política en re-

41 "Aproximación al estudio del vocabulario ideológico de Feijoo", CuH, 1979, núm. 347, p. 388. Para la palabra cultura, véase MARAVAll, art. cit., pp. 82-88.

42 Gregorio Mayans, Orígenes de la lengua española, Madrid, 1737, t. 1, p. 24 (edición facsímil, Atlas, Madrid, 1981). Debo este dato a Pedro Alvarez de Miranda que se tomó el interés de leerse la primera redacción de este trabajo. 
lación con el presente español. El contenido semántico de civilizar adquiere una dimensión ideológica reformista al significar la tarea colectiva que eliminando los obstáculos tradicionales permita al país superar el estado de decadencia y ponerse a la altura de los tiempos. Francisco Mariano Nifo lo adopta durante estos años para traducir del francés no sólo civiliser, sino también polir y policer, tres verbos que, sobre todo en las formas de participio, competían entre $\mathbf{s i}^{43}$. Como ahora veremos, las expresiones "nation policée", "nation polie", "nation civilisée" confluyen en "nación civilizada" al ser traducidas al español. Para "policer" no había un vocablo español equivalente. En el Nuevo diccionario francés español, de A. Capmany (Madrid, 1805), "policer'” se explica por "Poner, establecer policía o buen gobierno en algún pueblo, etc.' El español "pulir", por el francés "polir", tenía un sentido figurado muy débil: "Polir. v.a. ... (fig.) Pulir, civilizar: a las personas", en Capmany. En cambio, el nuevo verbo civilizar podía sustentarse fácilmente en la raíz de civil y civilidad y, por otra parte, respondía a la tendencia que civiliser mostraba en francés de asimilar, en su significación ampliada, tanto polir como policer.

En 1762, en una traducción del francés cuyo original desconozco, escribe Nifo:

Puede decirse que si viviéramos apartados de las mujeres, seríamos absolutamente diferentes de lo que somos. El cuidado que ponemos en adquirir sus favores, civiliza y endulza aquel tono adusto, y grosero, que no es menos que natural en nosotros.

La cita procede de un librito titulado El amigo de las mujeres, título que evidentemente recuerda el de L'ami des hommes ${ }^{44}$. El verbo francés que Nifo traduce por civilizar podría ser tanto civiliser como polir, ya que los efectos sobre los hombres que aquí se atribuyen a las mujeres coinciden con los ejemplos que da el diccionario de P. Richelet (1629) del primer verbo ("Civiliser. v.a. Rendre poli, civil, honnête. La conversation des Dames l'a un peu civilisé") y el de A. Furetière del segundo ("Polir, se dit figurément en Morale, et signifie premièrement, Giviliser. . . La conversation des Dames polit bien un jeune homme, le rend propre, ga-

43 Véase L. FebVre, op. cit., pp. 9-16.

44 El amigo de las mugeres. Traducido del Francés al Castellano. Por D. Francisco Mariano Nipho, Gabriel Ramírez, Madrid, 1763 (dentro, 1762), p. 12. En la dedicatoria a doña María Teresa Serra y Güel, leemos: "Para formar Heroínas agradables y virtuosas, útiles para sí y dignas por su mérito de la universal estimación (dicen muchos Eruditos) compuso el presente Tratado el Marqués de Mirabeau, altamente conocido por el Amigo de los Hombres. El origen, sea el que fuere, de donde viene el Amigo de las Mugeres, es muy alto", pero en el "Prólogo del autor"' se dice que la obra "ni es, ni debe entenderse una parodia, o trova, ni imitación del Amigo de los Hombres". Como es sabido, Mirabeau sólo escribió, hacia 1768, el borrador del principio de una obra que pensaba titular $L$ 'ami des femmes ou Traité de la civilisation, como ya indicamos antes en la nota 9. L. M. Enciso Recio, op. cit., p. 44, dice que el autor es Goguet. 
land et délicat'). Por otro lado, ya hemos visto cómo Mirabeau crea la palabra civilisation como substantivación del verbo con el signifícado de "adoucir", tal como lo vemos empleado en esta traducción de Nifo y que el mismo autor francés consideraba que la mayoría de sus lectores entendían "civilisation d'un peuple" como "l'adoucissement de ses mœurs"'. Esto es lo que en la traducción de Nifo se llama civilidad: "La civilidad tan decantada no es otra cosa que la dulzura practicada con arte" $^{45}$. Es esta civilisation o civilidad la que Mirabeau considera que no es más que "le masque de la vertu et non son visage"

Este civilizar y dulcificar el tono adusto de los hombres como resultado del esfuerzo que ponen en adquirir los favores de las mujeres abre el camino para una fácil caricaturización en la repetida sátira dieciochesca contra los petimetres, dirigida no sólo a ridiculizar las manifestaciones superficiales de lo moderno, sino también los auténticos anhelos de modernización y de reforma de las costumbres. Como indicamos en nuestro trabajo anterior, en El Pensador, de Clavijo y Fajardo, el verbo civilizar aparece como palabra de moda, caracterizadora de afectada modernidad en la jerga de los petimetres. Un aspirante, que hasta entonces había sido "hombre basto y, lo que es peor, a la antigua", empieza a practicar el obligado cortejo: "Para este fin - le escribe al redactor - he empezado a tomar un nuevo régimen de vida. Me estoy civilizando (como dicen los Corteji-cultos) y dejando las ridículas vejeces de mis costumbres antiguas" (IV, po. 269 y 271). En otro número, distingue El Pensador irónicamente a los maridos tolerantes, que son "civilizados", de los intolerantes, que son "muy malas bestias",47. Este tipo de sátira se hace lugar común y todavía más de veinte años después se publica en el Memorial literario una "tonadilla a solo" titulada Los civilizados que a Krauss le parecía una prueba del "desprestigio que sufría la noción de civilización entre los españoles del Xvin'"48. Decía una de las coplas de la tonadilla:

Cuando en el mundo un Usía

Con su mujer sólo es casto,

Dicen todos, se conoce

Que es hombre civilizado.

45 Op. cit., p. 115.

46 Véase Moras, op. cit., p. 38 y Benveniste, op. cit., p. 339.

47 "Es verdad que se ven muchos maridos civilizados, dóciles, discretos, sin curiosidad, sordos, ciegos, y afables; pero también hay otros, que son muy malas bestias, indiscretos, brutales, indigestos, incómodos, espantadizos, y que no creerían en un Cortejo, por muy taimado, y recatado que fuese" (I, 4, p. 29). Carmen Martín Caite (Usos amorosos del dieciocho en España, Siglo XXI, Madrid, 1972, pp. 135-136) comenta este pasaje. Este uso satírico de civilizar no impide que el verbo se utilice también en serio, por ejemplo: "no puede pedirse otra cosa a un Pueblo civilizado, que el tener leyes, por las cuales no queden impunes los delitos, y se asegure del modo posible la conservación de los Ciudadanos, y la tranquilidad del Estado" (III, 32, p. 126).

48 Art. cit., p. 439 , nota 7. 
Ya vimos cómo en el sainete de Ramón de la Cruz se atribuía satíricamente a los petimetres, con ciertas resonancias políticas, la tarea de civilizar al pueblo. Era una referencia al significado político con que el verbo civilizar aparecía en los periódicos de Nifo. En el Correo General de Europa se emplea repetidamente el nuevo verbo en la traducción de algunos extensos fragmentos de las Institutions politiques, del barón de Bielfeld, publicadas en 1760 en La Haya ${ }^{49}$. Según este periódico:

EI Barón de Bielfeld, Ayo y maestro del Príncipe Don Fernando, hermano del actual rey de Prusia, en sus Instituciones politicas (obra digna de leerse ad laudes et per horas) dándose a conocer como uno de los mejores médicos políticos de nuestra edad, ofrece un remedio convenientísimo para civilizar y pulir una Nación (I, p. 70; el subrayado es nuestro).

Uno de los fragmentos traducidos por Nifo en su periódico (I, pp. 70-90) es casi todo el capítulo cuarto, "De la manière de polir une Nation", del tomo primero. Se puede observar aquí el estado de vacilación léxica entre los verbos polir, policer y civiliser, y sobre todo de sus participios, en las expresiones "peuples policés", "peuples polis" y "peuples civilisés". En este capítulo, Bielfeld expone las ventajas que gozan estas naciones con respecto a una "nation barbare". En el original francés se emplea más frecuentemente el verbo polir que su sinónimo civiliser, ambos verbos traducidos por Nifo mediante el nuevo verbo civilizar, solo o acompañando al verbo pulir con un refuerzo copulativo ("civilizar y pulir"'), para intensificar la débil significación moral y política de este verbo en español. Para los participios se crea la sinonimia entre el nuevo participio civilizado y el antiguo adjetivo culto: las naciones cultas son a la vez naciones civilizadas. En cuanto al sustantivo, es politesse en el original francés el nombre que designa la condición por la cual los pueblos se hacen acreedores de uno de los tres participios franceses. También police, pero este sustantivo se reserva en las Insititutions polititques para un espacio estrictamente administrativo, ocupado por las leyes y el gobierno de una ciudad ${ }^{50}$. En este capítulo sobre cómo "civilizar y pulir una nación", con un sentido político, se trata de una "politesse" que, como en Voltaire, a cuya autoridad recurre Bielfeld en esta materia ${ }^{31}$, va mucho más allá de la simple urbanidad y cortesía. En el artículo "La notion de civilisation", Antoine Pelletier señala:

49 Aunque he consultado esta primera edición y la de París de 1762, las referencias que aquî́ hago son de la edición de Bassompierre, Lieja, 1768, que es la que tengo a mano al redactar este trabajo. La traducción completa de esta obra se debe a Domingo de la Torre y Mollinedo: Instituciones políticas. Obra en que se trata de la sociedad civit, de las leyes, de la policía, escrita en francés por el Barón dée Bielfeld y traducida al casteliano por Don. . ., 6 ts., Madrid, 1767-1801.

50 Véase L. FEBVRE, op. cit., pp. 12-14, sobre el significado de police.

51 Institutions politiques, ed. cit., t. 1, p. 59. 
la politesse devient chez Voltaire infiniment plus que cette urbanité par laquelle la définissait Furetière; elle englobera désormais, outre les mœurs et les lois, les arts, les sciences, la philosophie, tout cet acquis humain qui, loin de constituer la qualité plus ou moins innée d'un individu, représente la somme laborieuse et tangible d'une multitude d'efforts d'ordre collectif's'.

Así concebida, es un proceso histórico que desde los tiempos salvajes y bárbaros, en un desarrollo continuo, llega a su esplendor en el Siglo de las Luces. Ésta es la "politesse" que, en 1763, Nifo, falto de un término más adecuado, traduce por "civilidad" o también por "civilidad y pulimento político", donde al adjetivo "político" sirve para especificar este "pulimento" o "civilidad", distinguiéndolo de la pura cortesía y profundizando su contenido político y social. La vieja palabra civilidad amplía provisionalmente su sentido durante algún tiempo hasta que, sobrepasándola, sea sustituida por civilización. De "civilidad", como traducción de "politesse", se puede decir lo mismo que de esta palabra francesa dice Antoine Pelletier, que su concepto "se trouve enrichi, infléchi et bientôt dépassé au point de devoir céder la place à un mot nouveau d'import moins étroit" 53 .

En el Correo General de Europa, el concepto de "la Europa civilizada y culta" (I, p. 327) se corresponde con el de "la civilidad del siglo XviII" (I, p. 86). Citando a Bielfeld, Nifo cree que

No sería difícil de probar que la civilidad de una Nación, sus costumbres, la bondad de sus leyes, la prudencia y rectitud de su Gobierno: sus reglamentos interiores para sostener el buen orden y la sociedad: sus progresos en Artes y Ciencias depende únicamente de su opulencia; y que un Pueblo pobre (bien puede servir de comparación la España con todas sus riquezas) nada tiene de todo lo dicho, o lo tiene con mucha imperfección; y por consiguiente no es tan dichoso como lo podría ser (I, pp. 115-116, subrayado en el original).

En este contexto civilidad es un desarrollo nacional en el orden social, político, intelectual y moral, impulsado por la prosperidad económica y concebido dentro del concepto universal de felicidad. Opulencia económica, civilidad y felicidad son conceptos que van unidos. Los pueblos prósperos son pueblos civilizados y felices ${ }^{54}$. En cambio, en España:

entre los que comen y hambrean (que a esto se reduce nuestra España) estamos poco menos que sin pan y sin camisa. Las Ciencias están abandonadas; las Artes van de puerta en puerta; la aplicación general dormi-

52 En Matérialisme historique et histoire des civilisations, Éditions sociales, Paris, 1969, p. 12 .

53 Ibid., p. 11.

54 Sobre "felicidad" en el siglo xvilı español, véase JosÉ Ántonio Mĩaravall, "La idea de felicidad en el programa de la Ilustración", en Mélanges offerts à Charles Vincent Aubrum, Éditions Hispaniques, Paris, 1975, t. 1, pp. 425-462. 
da; el labrador casi tendido a la larga; y el magistrado, tímido de algún desaire contra sus providencias, oye, mira y calla; de todo esto resulta que va en aumento la pereza; toma más vuelo y altivez la ignorancia; y lo peor de todo es que el mal se empeora y el remedio se aleja (Correo General de Europa, I, p. 331).

Esta "civilidad del siglo XVIII" (p. 86) - "la politesse du XVIII siècle", según Bielfeld ${ }^{55}$ - unida al ideal profano de felicidad, es el concepto que Romea y Tapia considera venenoso, denominándolo civilización en 1763, cuando en Francia no sabemos de nadie que, fuera de Mirabeau, se atreviera a escribir ya la palabra civilisation, mientras que el concepto volteriano de progreso y desarrollo histórico todavía se denomina "politesse", como vemos en las Institutions politiques, de Bielfeld.

Para muestra de cómo, a partir de los verbos franceses polir y civiliser, empieza a emplearse en español el verbo civilizar para designar una acción política y social, y el correspondiente sustantivo civilidad, enriquecido su sentido paralelamente al de politesse, transcribimos a continuación algunos pasajes de las Instituciones políticas, traducidos por Nifo e incluidos en la carta VIII del Correo General de Europa (I, pp. 70-83). Forman parte del citado capítulo cuarto del primer tomo. Subrayamos las palabras cuyo original francés ponemos entre paréntesis.

Bielfeld comienza este capítulo dedicado al modo de civilizar una nación atacando la concepción rousseauniana "sobre la dicha del estado de la Naturaleza". Según la traducción de Nifo:

Hay genios extravagantes y bizarros que defienden que una Nación, viviendo en el estado simple de la Naturaleza, teniendo pocas necesidades, sin costumbres y sin civilidad (sans mœurs et sans politesse), tal, poco más o menos, como eran los Rusos antes de Pedro I, es de preferir a otra Nación civilizada, y culta (policée et maniérée), como la Francesa, la Británica, etc. ${ }^{56}$. . esto nos servirá de causa para tratar ligeramente las principales ventajas, y provechos que se seguirán a cualquier Reino de tener el Pueblo civilizado (quand le Peuple est civilisé). El Lector podrá comparar los efectos de la civilidad con lo que resulta de la barbarie, e ignorancia (Le Lecteur pourra les comparer avec ceux qui résultent de la Barbarie), y emplear las luces de la sana razón para deducir después las consecuencias (I, pp. 70-71).

Pulir, y civilizar una Nación (Polir une nation), es abrir los fundamentos de su gloria, y de su felicidad. Una Nación civilizada (Une nation policée) es mucho más fácil de gobernar que un pueblo grosero, y feroz. Las conspiraciones, y públicas inquietudes, son menos de temer donde se oyen las voces de la razón: . . el Zar Pedro no se habría visto precisado a exterminar los Streltsi, ni a emplear medios que horrorizan a la humanidad, si hubiera hallado en sus Dominios vasallos civilizados (Sujets plus policés)

55 Institutions politiques, ed. cit., t. 1, p. 67.

56 Rousseau reprocha a Pedro I haber querido "civiliser son peuple quand il ne failait que l'aguerir", apud L. FEBVRE, op. cit., p. 10. 
....En un Estado culto, y civilizado (Dans un État policé), hay un enlace poderoso entre las diferentes ramas del Gobierno, que todo lo sostienen en una armonía perpetua, y venturosa, y que previenen muy de antemano las revoluciones, y alborotos imprevenidos y funestos (I, pp. 71-72).

Según esta doctrina, un estado "culto y civilizado", "un état policé", es el que se ajusta a los principios del "despotismo ilustrado". Para los partidarios de esta concepción política, los motines populares de tres años después les iban a confirmar en su idea de que el pueblo español estaba todavía por civilizar. ¿Cuál es el concepto de "nation polie" en Bielfeld, de "nación civilizada" en la traducción de Nifo?:

Decir Nación civilizada (nation polie), es lo mismo que decir Nación, en la cual son muy numerosas las dependencias y las necesidades, y éstas son el origen de la industria, que cuando le toca su turno, se constituye madre de las Artes, de las Ciencias, de los Artes mecánicos, y finalmente, del Comercio. La reunión de todos estos objetos forma la felicidad del Estado. . . y últimamente, un Estado donde la Nación es civilizada (où la nation est polie) goza otra representación en el Mundo, y para la posteridad, que un Estado más o menos bárbaro. La experiencia de todos los siglos confirma lo que acabamos de proponer; pero sería muy conveniente haber referido todas las ventajas y prerrogativas que consigue sobre un Pueblo silvestre, o grosero, otro culto, y civilizado (d'un Peuple poli sur un Peuple sauvage). Este examen requería un volumen: Vea el Lector lo que han dicho sobre el asunto de los Escritores juiciosos, y exactos Políticos, que componen la Sabia Europa moderna (I, pp. 72-74).

¿Quiénes son estos escritores modernos a los que Nifo se refiere sin dar ningún nombre? El hecho es que en el texto original se nombraba a tres: "nous renvoyons le Lecteur à ce que les Montesquieu, les Voltaire, les Melon et tant d'autres illustres Auteurs de l'Europe moderne, ont dit si ingénieusement, et avec tant de verité, sur cette matière" 57 . Estos apellidos innominables también se omiten luego, cuando en 1767 , Domingo de la Torre y Mollinedo traduce toda esta obra de Bielfeld ${ }^{58}$. Aunque censurados en el texto español, no dejan de suministrar todo un trasfondo ideológico a las palabras que tanto Nifo como de la Torre y Mollinedo traducen por civilizar y civilidad.

Según esto, ¿qué es "pulir o civilizar una nación"? Es una acción política y, por lo tanto, una tarea del gobierno ilustrado:

La primera regla de la Política es, supuestos estos principios, que es necesario pulir una Nación (polir; civilizar en de la Torre y Mollinedo); esto es, dilatar las luces del espíritu, y formar el corazón del Pueblo por medio de costumbres dulces (mœurs douces), operación que los Latinos exprimen tan exactamente con la frase: Ad urbanitatem informare (I, p. 74).

57 Institutions politiques, ed. cit., t. 1, p. 59.

58 Instituciones políticas, ed. cit., t. 1, p. 65. 
Como vemos, en esta acción política se incluye "l'adoucissement des mœurs" en que consiste, como hemos visto, la civilisation en Mirabeau, si bien el sentido político con que aquí se entiende la acción de "former le cœur du Peuple à des mœurs douces", junto con "étendre les lumières de l'esprit" 59 , infunde a la noción de "urbanidad" el alcance semántico que se ha señalado en la concepción volteriana de "politesse". Urbanidad que incluye todas las virtudes civiles del ciudadano ilustrado, todos aquellos aspectos materiales y espirituales que llevan a la prosperidad y felicidad de una "nación civilizada":

la prosperidad del Estado mismo depende de la civilidad (Politesse générale) que reina en una Nación. Ahora pues, esta civilidad, o pulimento político (cette politesse), no puede existir si todo el Pueblo no es civilizado (n'est civilisé); esto es, si no está instruido hasta cierto punto, y si no tiene bien formado el corazón, y el juicio (I, p. 76).

Estos principios, por lo tanto, suponen que la "civilidad o pulimento político" (Politesse générale) es el resultado de la acción de civilizar o instruir a los ciudadanos, pero

no se trata solamente de civilizar (civiliser) una Nación bárbara, si la Providencia nos llama a el gobierno de su conducta; es también obligación de los Soberanos mantener en la civilidad, y buenas costumbres (d'entretenir dans la politesse) una Nación ya culta, y civilizada (qui est déjà civilisé) (I, p. 77).

De acuerdo con estas ideas, "la educación es el principio más noble, y más útil para la civilidad, y el pulimento político de una Nación" (L'Éducation est donc le principe de la politesse nationale) (I, pp. 78-79).

Nifo ofrece en su periódico los fragmentos de las Instituciones políticas con el propósito de que los lectores se formen "alguna idea del remedio que podría ser no sólo suficiente, sino muy eficaz para ahuyentar nuestros atrasos"' (I, p. 70). La idea del remedio se formula mediante el verbo civilizar. Consiste en trabajar para recuperar el tiempo perdido incorporando a la Nación a un proceso histórico en el progreso de las ciencias, las artes, la sociedad, seguido desde el Renacimiento por otros países europeos ("los reinos civilizados de Europa") del cual España quedó excluida. La idea se repite machaconamente en el Correo General de Europa. La vemos expuesta en el panorama del desarrollo histórico de las ciencias, trazado por el redactor en la carta tercera del primer trimestre (I, pp. 33-35). Desde el siglo xv, "primero en Italia, y sucesivamente en los demás reinos de Europa, restauró el hombre el gusto, que tanto tiempo había estado perdido: volvieron a su esfera los agrados de la vida; se civilizó el trato; se pulieron las conversaciones". 
Por lo que hemos leído en la traducción de la obra de Bielfeld, sabemos la trascendencia de este civilizar y este pulir en relación con la idea de restaurar las ciencias y sacudir "el yugo de la barbarie". La primera causa en la restauración de las ciencias en Italia

fue el ejemplo de algunas personas racionales y de gusto que desde el siglo XIV comenzaron a resentirse de la ignorancia que informaba a los hombres, y ellos, solícitos de su honor y enemigos del común desdoro, sacudieron el yugo de la barbarie. . . Este delicado estudio, siempre desatendido en España, y motivo de casi ningún progreso en las ciencias, pasó de Italia a Alemania; de aquí a Inglaterra; también la Francia tomó partido en negocio de tan dichosas consecuencias: nuestra España quedó mirando el espectáculo, y todavía permanece en el oficio de simple espectadora y los reinos sobredichos siguen representando el papel decoroso de su felicidad en el cultivo de las ciencias.

Considerada así la situación del país, "civilizar la Nación” se convierte en fórmula regeneradora en consonancia con un nuevo vocabulario y una nueva ideología. Civilizar es modernizar. A pesar de las sátiras de los Romea y Tapia y los Ramón de la Cruz, a pesar de que la palabra les parezca malsonante a algunos, el verbo ha cruzado los Pirineos para naturalizarse. Viene a llenar una necesidad expresiva en el vocabulario ideológico del siglo XviII, como se puede ver por los ejemplos posteriores que ofrece Maravall en su trabajo citado sobre la palabra civilización.

\section{CIVILIZACIÓN DESDE 1765}

El verbo civilizar era la base léxica necesaria para el sustantivo civilización. Ambas palabras quedan registradas tempranísimamente en un diccionario español. Antes de 1765, cuando la sustantivación de civili$z a r$ sólo ha podido ser atestiguada cinco o seis veces en Mirabeau, y tres en español en unas circunstancias muy precisas, el jesuita Esteban de Terreros y Pando la incorpora a su Diccionario castellano con las voces de las ciencias y artes, obra a la que se le concede la Licencia del Juez de Imprentas Juan Curiel por decreto del 27 de enero de 1765. Aunque no se publicó hasta 1786, la impresión se había iniciado en la imprenta de Ibarra veintisiete años antes, quedando interrumpida cuando iba por la mitad del segundo tomo al ser expulsados de España los jesuitas ${ }^{60}$. Así es que se puede afirmar que el diccionario de Terreros no sólo es

60 El diccionario de Terreros fue editado en cuatro tomos por Francisco Meseguer Arrufat y Miguel de Manuel Rodríguez, a instancias de Floridablanca, entre 1786 y 1793. Sobre los datos de la edición, véase la carta dedicatoria de los editores al conde de Floridablanca en el primer volumen de la obra y las "Memorias para la vida y escritos del P. Estevan de Terreros" en el cuarto volumen, pp. v-xiv. 
el primer diccionario español que incluye la voz civilización, sino también el primero en cualquier lengua que además de la acepción forense indica el nuevo significado de la acción de civilizar un pueblo. En el primer tomo, impreso en 1765 , encontramos efectivamente la palabra que buscamos: "Civilización, término forense, acto de justicia que hace civil una causa criminal. Fr. Civilisation. También se puede decir de la acción de civilizar, y domesticar algunos pueblos silvestres: la civilización de los brasileños fue muy difícil para los Misioneros"'. Tanto por la definición, como por el ejemplo, la acción de civilizar se concibe aquí todavía en un plano muy elemental; significa dar apenas el primer paso en la organización social, lejos aún del progreso en las ciencias, artes y costumbres que la acción de civilizar indica en los periódicos de Nifo y muy por debajo de la moderna civilidad o pulimento político ("politesse", "police") a que han llegado los pueblos civilizados de Europa. El ejemplo de Terreros se parece mucho a uno de los propuestos por Furetière en 1690, en su Dictionnaire universel, para ilustrar el verbo civiliser: "La prédication de l'Évangile a civilisé les peuples barbares les plus sauvages", repetido luego por el Dictionnaire de Trévoux. Recordemos que en el primer ejemplo de Mirabeau, la civilisation es un efecto laico de un impulso religioso ${ }^{61}$.

L. Febvre, que no conocía ningún ejemplo de civilisation anterior a 1766 , considera la década de 1765 a 1775 el período en que el neologismo conquista "ses lettres de naturalité"'62 en Francia. Después de Mirabeau, la palabra aparece en Boulanger (1766), Baudeau (1767), Linguet (1767), Dupont de Nemours $(1769)^{63}$. Con ejemplos de Diderot, d'Holbach, Raynal, señala con precisión J. Moras el año 1774 como la fecha de admisión del neologismo en el vocabulario de los enciclopedistas ${ }^{64}$. Sin embargo, como observa Febvre, "il ne se rencontre cependant point partout" 65 . Aunque en español, a pesar de los antecedentes autóctonos de 1763 y el testimonio de Terreros, la utilización es aún más limitada, es también, más o menos, durante la misma década cuando civilización se naturaliza en España. Mis lecturas de textos de la época no son bastante extensas, pero puedo aportar ejemplos

61 Según Benveniste, op. cit., pp. 340-341, civilisation "n'était pas seulement une vue historique de la sociéte; c'était aussi une interprétation optimiste et résolument non théologique de son évolution qui s'affirmait, parfois à l'insu de ceux qui la proclamaient, et même si certains, et d'abord Mirabeau, comptaient encore la religion comme le premier facteur de la 'civilisation' ',

62 L. FEbVRE, op. cit., p. 6.

63 Para ejemplos de estos autores, véanse las obras citadas de Febvre, Moras y Benveniste.

64 Op. cit., p. 51 . Moras señala que en la primera edición de la Histoire philosophique et politique des établissements et du commerce des Européens dans les deux Indes, de 1770 Raynal no utiliza la palabra civilisation, que aparece en la segunda edición, de 1774 y su uso aumenta en la tercera, de 1780 . Por lo visto, L. Febvre se atuvo a esta tercera edición, op. cit., p. 7 y nota 13 .

65 L. FebVre, op. cit., p. 7. 
de 1769 y 1773 , a mi parecer, lo suficientemente significativos para considerarlos como indicio de que el neologismo ya empezaba a emplearse con cierta normalidad. Como es bien sabido, la aparición impresa de una palabra no señala siempre la primera fecha de su creación. Así como hemos visto que civilizar se considera una palabra característica de las conversaciones de los petimetres, también podemos suponer que primero el verbo y luego la sustantivación no fueran demasiado insólitos en la lengua culta hablada de los españoles de la época.

En la traducción de los Viaggi di Enrico Wanton alle terre incognite Australi, ed al paese delle Scimie, de Zaccaria Seriman (Venecia, 1749), publicada en 1769 por Gutierre Joaquín Vaca de Guzmán y Manrique ${ }^{66}$, nos tropezamos con la palabra civilización para traducir el término italiano coltura, a pesar de que el español cultura, como ha mostrado Maravall, ya tenía una tradición prestigiosa. En el original italiano leemos el siguiente pasaje: "Oh quanto è facile rimprovare, e schernire in altri li medesime nostri diffeti, e chiamar barbari qu'e costumi, che apresso noi sono intitolati coltura e politezza" 67 , y en la traducción española: “ ¡Oh, qué fácil es desaprobar, y escarnecer en otros nuestros mismos defectos, y dar título de bárbaras a aquellas propias costumbres que entre nosotros llamamos civilización, y política!' 68 La misma idea la encontramos en el primer ejemplo que Benveniste da de civilization en inglés, en una obra publicada en 1767 por Adam Ferguson: "We are ourselves the supposed standards of politeness and civilization" 69 .

Otro ejemplo de civilización en el mismo autor español es más tardío, de 1778, en el Suplemento original, o continuación por cuenta del traductor de los viajes de Enrique Wanton. Invitado el viajero a comer en casa de una marquesa del país de las monas, después de la comida se organiza una partida de cartas:

Convidome madama a que concurriese o hiciese partido; pero yo escusándome, hube de pasar plaza de incivil, que a tal término había allí llegado esta pasión dominante del juego, que ya era capítulo de su decantada civilización, y crianza ${ }^{70}$.

66 Viages de Enrique Wanton a las tierras incógnitas australes, y al país de las monas. . Traducidos del idioma inglés al italiano, y de éste al español. Por D. Joaquín de Guzmán y Manrique, María García Briones, Alcalá, 1769. El original inglés es ficticio. Sobre esta obra, véase D. M. White, Zaccaria Seriman 1709-1784 and Viaggi di Enrico Wanton, Manchester University Press, Manchester, 1961. Sobre la traducción española, JosÉ EsCOBAR y ANThony Percival, "Viaje imaginario y sátira de costumbres en la España del siglo XVIII", en M. Rösner y B. Wagner (eds.), Aufstieg und Krise der Vernunfi. Homenaje a Hans Hinterhäuser, Böhlau, Wien, 1984.

67 Viaggi di Enrico Wanton, Giovani Tagier, Venecia, 1749, t. 1, p. 79. Hay edición moderna de Gilberto Pizzamiglio, Marzorati, Milán, 1977. El subrayado es mío.

68 Ed. cit., t. 1, pp. 59-60. El subrayado es mío.

69 Apud Benveniste, op. cit., p. 343.

70 Suplemento, o sea, tomo tercero de los Viages de Enrique Wanton. . . Ordenado y dado a luz de unos manuscritos ingleses. Por Don Joaquín de Guzmán y Manrique, Sancha, Madrid, 1778 , p. 142. 
Aquí civilización es la máscara social que Mirabeau consideraba "fausse civilisation" y que en la traducción del Amigo de las mujeres, de 1762, era "la decantada civilidad".

Después del ejemplo de Vaca de Guzmán, de 1769, encontramos de nuevo la palabra en 1773, con toda la plenitud ideológica de la Ilustración, en el Comentario sobre el Doctor festivo y Maestro de los Eruditos a la Violeta, para desengaño de los Españoles que leen poco y malo, por Pedro Fernández, seudónimo de A. Capmany ${ }^{71}$. El autor catalán critica en este Comentario las observaciones de Cadalso, en Los eruditos a la violeta, contra la carta de las Lettres persannes, de Montesquieu, en que se satirizan el carácter y las costumbres de los españoles. A pesar de su intención crítica, Pedro Fernández quiere mantener su controversia en un tono civilizado: "no fundo la emulación en las disputas literarias, que casi siempre no han sido otra cosa que el desahogo del odio personal, la sangrienta tenacidad de los partidos y el borrón de una Nación civilizada'" (p. 184). En tres pasajes del Comentario, el joven Capmany emplea la palabra civilización en unas páginas que son ejemplo del nuevo vocabulario de la Ilustración:

El mismo Montesquieu, no olvidaría el diluvio de invectivas, tan groseras como sangrientas, contra sus Paisanos, con que algunos escritores nuestros del siglo pasado inundaron el público, prostituyeron la Prensa y deshonraron su propia Nación. Hoy en día, las Naciones forman una confraternidad general, y aquellos sucios escritos nos demuestran que aquellos tiempos no habían alcanzado la última civilización (p. 188).

Si yo pudiera resolverme a creer que $\mathrm{Vm}$. ignoraba cuánta es la ventaja de este siglo sobre los precedentes, en el uso de la Razón humana. Pero ¿qué? Vm. lo sabe, así como sabe también que nosotros somos de los que menos hemos contribuido para hacer la Europa moderna, tan superior a la antigua: mas la gloria de este todo cubre a todas sus partes. . . hoy cuesta menos tiempo, y menos trabajo, el instruirse e iluminarse, porque tenemos modelos que imitar: porque otros nos abren y construyen el camino; porque toda Europa es una escuela general de civilización (pp. 201-202).

Acuérdense que los Médicis, recibiendo en un mismo día Embajadores de los Reyes y las Drogas de sus Factores, resucitaron las artes, las ciencias y el buen gusto, que había sepultado la mano exterminadora de los Hunnos y los Vándalos, azote de la civilización (p. 215).

Estos pasajes del joven escritor revelan ya un uso normal de la nueva palabra, tanto en cuanto estado ("la última civilización", "azote de la civilización") como en cuanto acción de civilizar, implícita en la idea de que "toda la Europa es una escuela de civilización". El ideal representado por el neologismo es un ideal de progreso y de perfectibilidad

71 Edición de Julián Marías, La España posible en tiempo de Carlos III, Estudios y publicaciones, Madrid, 1963, pp. 181-218. Nigel Glendinning demostró que Pedro Fernández era seudónimo de A. Capmany, en "A note on the authorship of the Comentario sobre el Doctor Festivo. . .", BHS, 43 (1966), 276-283. 
que se desprende de todas las páginas del Comentario: "la perfectibilidad es el don más precioso que el Cielo concedió al hombre, para distinguirlo de los Brutos" (p. 214). La preocupación principal a que todas las reflexiones de Pedro Fernández van dirigidas es la España de su tiempo, en relación con el conjunto de Europa, y señala, en consecuencia, "el recto camino de la razón Española, que hasta aquí se ha extraviado" (p. 185). Pero advierte que "la obra de perfeccionar una Nación es una obra larga". La "obra de perfeccionar" es la acción de civilizar. El año siguiente, el año en que los enciclopedistas empiezan a usar la palabra, d'Holbach dirá:

La civilisation complète des peuples, et des chefs qui leur commandent, la réforme désirable des gouvernements, des mœurs, des abus ne peuvent être que l'ouvrage des siècles, des efforts continuels de l'esprit humain, des expériences réitérées de la société ${ }^{72}$.

En este contexto, con el anhelo de perfeccionar la Nación, se inscribe en estas páginas el sentido de la palabra civilización, entendida como obra de civilizar, es decir, en el sentido en que este verbo empezó a emplearse en los primeros años de la década anterior. La conciencia de atraso y decadencia y sus posibles remedios, que provocó en 1763 la polémica de la cual surgió civilización como sustantivación de civilizar, continúa vigente en este escrito de Capmany.

De la manera como se emplea la palabra en este manuscrito de 1773 puede decirse lo mismo que señala Maravall de otro texto seis años posterior, del mismo Capmany, el prólogo a sus Memorias históricas, Comercio y Artes de la ciudad de Barcelona (1779), donde la palabra civilización vuelve a aparecer: "el uso que de ella hace revela que es cosa en él habitual y no menos en el sector al que su obra se dirige". Y añade: "Es más, nos hace ver que se emplea ese término en la polémica sobre el estado cultural de España, ya que a este tema se refiere Capmany ${ }^{73}$. En dicho prólogo, piensa Capmany que si se hubiera escrito una historia del comercio marítimo de otras partes del país, "su publicación hubiera puesto silencio a la osadía, ligereza o ignorancia de algunos escritores extranjeros que nos colocan en la clase de las naciones donde menos progresos hizo la civilización"74. En efecto, la intuición de que, cuando se escribe este texto, civilización era una palabra habitual en su autor queda corroborada por el manuscrito de 1773 en el que también se emplea el neologismo en la polémica sobre el estado cultural de España; lo cual nos lleva de nuevo a la polémica del año 63 sobre si España era un país civilizado o estaba todavía por civilizar. Pero si en 1773, Capmany, con más destreza literaria que Nifo, coincide con éste en que los españoles habían sido los que menos habían contribuido a crear la Europa mo-

\footnotetext{
72 Apud L. Febvre, op. cit., p. 21.

73 "La palabra 'civilización'. . .", p. 99.

${ }^{74}$ Apud Maravall, ibid.
} 
derna, limitándose al papel de mirones ${ }^{75}$, en 1779 quiere mostrar la contribución de España a la tarea de la civilización general en contra de los extranjeros -y de algunos españoles como Pedro Fernández- que afirman lo contrario.

Sea como fuere, civilizar y civilización se incorporan al vocabularo español del siglo XviII para cumplir la necesidad de expresar una concepción moderna de la vida y de la sociedad, y en consecuencia la acción de remediar el atraso histórico en que se encuentra España con respecto a los países que han llegado a un estado de civilización, ¿de "última civilización", según Capmany? Pero por ello mismo, por su prestigio entre los reformadores, la oposición reaccionaria contra el neologismo continúa, como podemos ver en un testimonio muy significativo de esta misma época aportado por Pedro Álvarez de Miranda, en el aparato crítico del estudio preliminar a su citada edición de la utopía anónima antiilustrada, Tratado sobre la Monarquía Columbina. Álvarez de Miranda reproduce un breve fragmento de un manuscrito de 1777, El lujo en su luz y Voltaire refutado, redactado por Miguel Antonio de la Gándara en la cárcel de Pamplona, donde estaba preso a raíz del motín de Esquilache $^{76}$. El uso que en este escrito se hace del verbo civilizar y del sustantivo civilización atestigua tanto la difusión de estos términos como característicos del vocabulario de los ilustrados ("filósofos") a cuya ideología se opone el autor del Voltaire refutado, como la persistencia de la polémica ideológica iniciada en 1763 en torno a dichos neologismos. El fragmento dice así:

Que el lujo no civiliza a nadie. (¡Válgate Dios por civilización! ¡Qué en gracia has caído delante de los filósofos!). . .

Quien civiliza al hombre, señor Voltaire, es (créalo Vm.) la ciencia del evangelio, el cumplimiento de sus preceptos, la observancia de sus consejos, la práctica de sus máximas, el uso de sus instrucciones, la creencia de sus misterios, el arreglo a su Moral y la adhesión invariable a sus verdades eternas.

Ésta, ésta, Monsieur, es la civilización de las civilizaciones. Y todos los que tienen seso en la cabeza o sal en la mollera vienen a civilizarse en la doctrina y estudio radical de este libro, civilizador supremo. No hay otra

75 En la introducción ("Idea de esta obra") del Diario Extranjero, Nifo explica: "Pues para que veamos lo que hacen nuestros vecinos he intentado este Diario Extranjero, no con otro fin, sino para que hagamos algún papel en el mundo; y ya que en su dilatado teatro no seamos representantes, hagamos siquiera el insulso papel de mirones, que de los actos repetidos de mirar, puede ser consigamos el hábito de conocer'. Ya hemos visto cómo en el Correo General de Europa se decía que en el progreso de las ciencias "nuestra España se quedó mirando el espectáculo, y todavía permanece en el oficio de simple espectadora".

76 En el Voltaire refutado, Gándara contradice la ideología de sus Apuntes sobre el bien y el mal de España (1759) donde elogia a Voltaire entre otros autores franceses, como Montesquieu y Rousseau, comparándolos con Homero, Demóstenes y Cicerón. (En Almacén de frutos literarios, inéditos de los mejores autores, Viuda de López, Madrid, 1820, t. $2, \mathrm{p}, 41$ ) 
escuela. No hay otra filosofía. Aquí está la ilustración verdadera. Y fuera de él también está. . ¿ ¿qué? La perdición sempiterna ${ }^{77}$.

Aunque Voltaire, interpelado aquí sobre el concepto de civilización, nunca utilizara el neologismo, civilización y civilizar eran términos identificados con la ideología de la Ilustración representada en Voltaire por antonomasia. El paréntesis de Gándara, refiriendo civilización a civilizar, recuerda el de Romea y Tapia en que también la sustantivación se utiliza para desprestigiar el uso del verbo por los reformistas ${ }^{78}$. Como en El escritor sin título y en el sainete La civilización, en el Voltaire refutado se ataca a los ilustrados con su propio vocabulario, subrayando los neologismos para marcar su intertextualidad. Gándara se apropia del vocabulario de sus contrarios, invirtiendo su significación ideológica por medio de la sacralización de su contenido laico. "La civilización de las civilizaciones", "la ilustración verdadera" aluden a la civilización y a la ilustración sin determinantes, conceptos dañinos y venenosos. Bóhl de Faber, heredero de este pensamiento reaccionario dieciochesco (una de sus autoridades es precisamente Romea y Tapia) ${ }^{79}$, también distingue polémicamente de lo que se entiende en el día por ilustración, "la verdadera ilustración", la "ilustración nacional", "la ilustración española", identificando el concepto con el carácter nacio$\mathrm{nal}^{80}$. Ilustración y civilización se convierten en conceptos casticistas ${ }^{81}$.

Entre 1763 y 1779 hemos visto utilizada la palabra civilización por varios autores: Romea y Tapia y Ramón de la Cruz en 1763, Terreros en 1765, Joaquín Vaca de Guzmán en 1769 y 1778, Capmany en 1773 y 1779, Gándara en 1777 y seguramente habrá otros ejemplos del mismo período. Con estos testimonios hemos llegado en la historia de la palabra al punto donde la había iniciado Maravall, después del título sainetesco que le parecía un "antecedente inesperado" y cuyas circunstancias hemos tratado de aclarar aquí examinando el uso del verbo civilizar, necesario, como condición previa, para que la derivación alcanzara su vigencia. Este examen nos ha permitido precisar las condiciones conflictivas con que surge el neologismo en el vocabulario español del siglo XVIII como un reflejo de la confrontación ideológica entre dos mentalidades, el casticismo y la europeización; confrontación característica del nacimiento y del desarrollo de la España moderna y de su revolución burguesa.

JosÉ EsCOBAR

Glendon College, York University.

77 Apud P. Álvarez De MiRanda, op. cit., pp. 41-42.

78 Véase supra, p. 95.

79 Véase supra, nota 30

80 Véase Guillermo Carnero, op. cit., pp. 177-178 y 260-261.

$81 \mathrm{~J}$. A. Maravall (art. cit., 103-104) considera expresada la concepción casticista de civilización en el libro de Gonzalo Morón, Historia de la civilización española, publicado en 1841 . 